\title{
Phytochemical Screening and Antioxidant Activity of Strawberry Juice (Fragaria ananassa Duchessne) Against Ureum Level, Creatinin, and Enzyme Catalase Activity In Isoniazid-Induced Wistar Male Rats
}

\author{
Endang Sri Sunarsih ${ }^{1 *}$, Ebta Narasukma Anggraeny², \\ Patricia Sanggita Listyoputri Wibowo ${ }^{2}$, Novi Elisa ${ }^{2}$ \\ ${ }^{1}$ Universitas Diponegoro, Indonesia \\ ${ }^{2}$ Sekolah Tinggi Ilmu Farmasi Yayasan Pharmasi Semarang, Indonesia \\ *endss2007@yahoo.co.id
}

\begin{abstract}
Kidney are vital organ for human. Isoniazid is an antituberculosis drug that causes multilobular necrosis and acute tubulointerstitial nephritis (ATIN). Isoniazid nephrotoxicity in kidney is able to trigger oxidative stress through the formation of reactive oxygen species (ROS). ROS increase can causes damage to the kidney so that urea and creatinine level increase in the blood and can be used as a marker of decreased kidney function. Excessive free radicals can cause a decrease in endogenous antioxidant activity, namely the catalase enzyme. This condition can be overcome by given exogenous antioxidants such as strawberry juice (Fragaria ananassa Duchessne). This study aimed to determine the effect of strawberry juice treatment against urea and creatinine levels in male Wistar rats Isoniazidinduced for 14 days divided into groups, namely normal control, negative control, positive control, strawberry juice dose of $3 \mathrm{~g} / \mathrm{kgBW}, 6 \mathrm{~g} / \mathrm{kgBW}$, and $9 \mathrm{~g} / \mathrm{kgBW}$. Data were collected on 1st, 15th, and 29th day. The results of the study concluded that strawberry juice had an effect in reducing levels of urea, creatinine and catalase enzyme activity in isoniazid-induced rats with an effective dose of $3 \mathrm{~g} / \mathrm{kgBW}$.
\end{abstract}

Keywords: Catalase Enzym, Creatinin, Isoniazid, Strawberry Juice, Ureum 


\section{STRADA Jurnal Ilmiah Kesehatan}

DOI: $10.30994 /$ sjik.v9i2.510

ISSN: 2252-3847 (print); 2614-350X (online)

Vol.9 No.2 November 2020 Page. 1595-1604

\section{BACKGROUND}

Kidney are vital organ for human. Kidney have a role for the body as the disposal of Non-protein Nitrogen compound (NPN), regulator of body fluid balance, regulator of electrolyte balance, and regulator of acid-base balance (Verdiansah, 2016). Impaired kidney function occurs when the body fails to maintain metabolism and balance of fluids and electrolytes resulting in retention of urea and other nitrogenous wastes in the blood (Brunner \& Suddarth, 2001).

Isoniazid is the most important anti-tuberculosis (OAT) drug for the prevention and treatment of tuberculosis (TB), either as monotherapy or in combination with other TB drugs (Rahman, 2013). There are quite a lot of side effects caused by isoniazid, one of whic is can cause multilobular necrosis (Katzung, 2008). Isoniazid also has an effect on the kidney, called acute tubulointerstitial nephritis (ATIN) (Appel \& Bhat; 2006 Baker \& Pusey 2004). Isoniazid nephrotoxicity in the kidney is capable to inducing oxidative stress through the formation of reactive oxygen species (ROS). The increase in reactive oxygen species will cause damage to the kidney (Sharma, 2012).

Investigation of kidney function damage can be seen from the levels of substances that are filtered by the glomerolus by the blood, such as creatinine and urea. If there is a decrease in renal function and the GFR rate decreases, the creatinine and urea levels filtered by glomerulus will decrease, so that their levels in the blood will increase. Increased levels of urea and creatinine in the blood can be used as a marker of decreased kidney function (Guyton and Hall, 2008). High serum urea and creatinine levels can occur in chronic renal failure and hemodialysis therapy does not reflect a decrease in serum urea and creatinine levels back to normal (D G A Suryawan et al, 2016).

In addition, excessive free radicals can also cause a decrease in endogenous antioxidant activity, including catalase enzyme. Catalase is an enzyme that converts hydrogen peroxide into water and oxygen molecule. Hydrogen peroxide $(\mathrm{H} 2 \mathrm{O} 2)$ is one of the free radical. Excessive $\mathrm{H} 2 \mathrm{O} 2$ is a toxic source of various diseases because it can cause tissue damage (Untari, 2014). Catalase enzyme plays a role in controlling the concentration of $\mathrm{H} 2 \mathrm{O} 2$ by catalyzing $\mathrm{H} 2 \mathrm{O} 2$ so that it is less even non-toxic (Apriana et al., 2016: 36).

An effort to overcome health problems, especially kidney, are by using antioxidants (Kumalaningsih, 2007). One of the exogenous antioxidants of natural substance is strawberry. Strawberry is a fruit that is often consumed by the public and easy to find out. Strawberry have a high content of antioxidants and phenolic compounds (Oszmianski et al., 2009). The main class of phenolic compounds is represented by flavonoid (mainly anthocyanin, with flavonol acting as minor contributor), followed by hydrolyzed tannin (ellagitannin and gallotannin) and phenolic acid (hydroxybenzoic and hydroxycinnamic acid), and condensed tannin (proantocyanidin) (Kahkonen et. al., 2001; Aaby et al., 2005).

Based on the description above, can be assumed that strawberry have antioxidant activity as a nephroprotector. This study was done to determine the effect of strawberry juice (Fragaria ananassa Duchessne) treatment on urea levels, creatinine, and catalase enzyme activity in Isoniazid-induced male rats at dose of $200 \mathrm{mg} / \mathrm{kgBW}$.

\section{METHODS}

Ingredients. Ingredients that used were strawberry fruit, male Wistar rats, aquadestilata, isoniazid from PT Phapros, Curcumin p.a, CMC Na, Picric acid, Sodium hydroxide, Disodium phosphate, Tris buffer ( $\mathrm{pH}$ 7.60) , ADP, $\alpha$-ketoglutarate, Urease, $\mathrm{GIDH}$, Sodium azide, $\mathrm{NADH}, \mathrm{NaOH}, \mathrm{HCl}, 50 \mathrm{mM}$ potassium phosphate buffer ( $\mathrm{pH} 7.0$ ), hydrogen peroxide $\left(\mathrm{H}_{2} \mathrm{O}_{2} 10 \mathrm{mM}\right)$, and $32.4 \mathrm{mM}$ ammonium molybdate. 


\section{STRADA Jurnal Ilmiah Kesehatan}

DOI: $10.30994 /$ sjik.v9i2.510

ISSN: 2252-3847 (print); 2614-350X (online)

Vol.9 No.2 November 2020 Page. 1595-1604

Equipment. Equipment that used in this study were scale (digital and analytical), juicer, beaker glass, glass funnel, stirring rod, centrifuge tube, capillary tube, measuring cup, animal cage, injection syringe with blunt tipped needle, centrifuge (Gemmy centrifuge PLC05), micropipette, asbestos, stative, thermometer, clamp, UV-VIS Spectrophotometer, and Spectrophotometric Mikrolab 300.

Making Strawberry (Fragaria ananassa Duchessne) Juice. Fresh fruit that had been sorted, washed, cleaned from the leaves then weighed according to the calculation. Put the strawberry fruit into the juicer and extract the juice from the fruit. Juice then collected in a container. Volume of strawberry (Fragaria ananassa Duchessne) juice measured. Juice in a measuring cup to determine volume that obtained. Put in into a bottle that protected from sunlight and stored in the refrigerator.

Strawberry (Fragaria ananassa Duchesne) Juice Phytochemical Screening. The preliminary tests that have been done include:

\section{Flavonoids}

Strawberry juice (Fragaria ananassa Duchessne) was put in a test tube, added with $\mathrm{Mg}$ powder and $1 \mathrm{ml}$ of concentrated $\mathrm{HCl}$, then added amyl alcohol, shaked vigorously and allowed to separate, the changes were observed (Harborne, 1987: 73). The presence of flavonoid compounds was indicated by the formation of a red or orange color in amyl alcohol compound (Endarini, 2016).

\section{Tannin}

Strawberry juice (Fragaria ananassa Duchessne) was added to a test tube with $10 \%$ $\mathrm{NaCl}$ added, then filtered and the filtrate was taken. The filtrate was divided into two, called filtrate A and B. Filtrate A was added with $1 \%$ gelatin. Positive result if a white precipitate was formed. Filtrate B added with $10 \% \mathrm{FeCl} 3$ solution. Positive results occured in dark green or bluish green (Endarini, 2016).

\section{Saponin}

Strawberry juice (Fragaria ananassa Duchessne) was put in a test tube, added $10 \mathrm{ml}$ of hot water, cooled and then shaked vigorously for 10 seconds. The reaction is positive if a stable foam was formed for not less than 10 minutes with 1 to $10 \mathrm{~cm}$ high. With the addition of 1 drop of $2 \mathrm{~N}$ hydrochloric acid, the foam did not disappear (MOH, 1979: 170).

\section{Alkaloids}

Strawberry juice (Fragaria ananassa Duchessne) was put in a test tube then mixed with $1 \mathrm{ml}$ of $2 \mathrm{~N} \mathrm{HCl}$ and $9 \mathrm{ml}$ of hot aquadest. The solution was heated for 2 minutes, then cooled and filtered. Filtrate was put into 2 test tubes. The first tube was added with Dragendroff reagent and the second tube was added with Mayer reagent (Depkes RI, 1995). The positive results of alkaloids were indicated by the formation of a reddish brown precipitate when Dragendroff reagent is added and a white precipitate is formed when the Mayer reagent is added (Endarini, 2016).

\section{Steroids and Triterpenoids}

Strawberry juice (Fragaria ananassa Duchessne) was put into a test tube mixed with ether, then filtered and the filtrate was taken. The filtrate was evaporated in an evaporator cup until a residue was obtain. The residue was added with 2 drops of anhydrous acetic acid and 1 drop of concentrated sulfuric acid. The presence of terpenoid was indicated by the appearance of a red color while the presence of steroid was indicated by the appearance of a blue color (Endarini, 2016). 


\section{STRADA Jurnal Ilmiah Kesehatan}

DOI: $10.30994 /$ sjik.v9i2.510

ISSN: 2252-3847 (print); 2614-350X (online)

Vol.9 No.2 November 2020 Page. 1595-1604

The Confirmation Test or TLC of Strawberry Juice (Fragaria ananassa Duchessne) includes:

\section{Flavonoids}

Eluent that used were n-butanol: glacial acetic acid: water (4: 1: 5) and then separated to take the n-butanol phase. The plate was sprayed with ammonia vapor. The formation of a brownish yellow color indicates the presence of flavonoids (Robinson, 1995: 211).

\section{Tannin}

Eluent that used were toluene: ethyl acetate (3: 1). The plate were sprayed with $\mathrm{FeCl}_{3}$. The formation of a green-black color indicates the presence of tannin compounds (Robinson, 1995: 78)

\section{Saponin}

The eluent used were chloroform: methanol: water (64:50:10). The plate were sprayed with the sulfuric acid anisaldehyde then oven at $100{ }^{\circ} \mathrm{C}$ for $5-10$ minutes. Green or blue color in UV light indicated the presence of saponin compounds (Nuria et al., 2009).

\section{Alkaloids}

Eluent used were ethyl acetate: methanol: water (100: 13,5: 10). The plate was sprayed with dragendorf reagent. Alkaloid compounds occured a brown or orange color (Arifin et al., 2006).

\section{Triterpenoid}

Eluent used were toluene : ethyl acetate (93:7) and detected using anisaldehyde-sulfuric acid (oven $110{ }^{\circ} \mathrm{C}$ for $5-10$ minutes). formation of red, purple, dark purple, green, blue, red spots indicated positive triterpenoid compound (Hayati et al., 2012).

Experimental Animal Treatment. This research was used 30 rats and divided into 6 groups, called group I (normal control), group II (treated with CMC Na 0.5\%), group III (treated with Curcumin $50 \mathrm{mg} / \mathrm{kgBW}$ ), group IV (treated with strawberry juice at dose $3 \mathrm{~g} / \mathrm{kgBB}$ ), group V (treated with strawberry juice at dose $6 \mathrm{~g} / \mathrm{kgBB}$ ), and group VI (treated with strawberry juice at dose $9 \mathrm{~g} / \mathrm{kgBB}$ ). Group I was given standard feed (bio rat) and drink, while groups II, III, IV, V, and VI were given $200 \mathrm{mg} / \mathrm{kgBW}$ of isoniazid induction for 14 days. Furthermore, treatment was given according to each group for 14 days. Measurement of urea and creatinine levels was carried out on day 1 st, day 15 th and day 29th. The data obtained were analyzed using SPSS version 19.

Measurement of the enzyme catalase activity. $100 \mu \mathrm{l}$ of blood serum was measure and $2000 \mu \mathrm{l}$ of $50 \mathrm{mM}$ potassium phosphate buffer ( $\mathrm{pH} 7.0$ ) containing $10 \mathrm{mM}$ of hydrogen peroxide $\left(\mathrm{H}_{2} \mathrm{O}_{2}\right)$ was added (Iwai et al., 2002). The solution was incubated at $37{ }^{\circ} \mathrm{C}$ for 1 minute and then added $1.0 \mathrm{ml}$ of $32.4 \mathrm{mM}$ ammonium molybdate $\left.\left[\left(\mathrm{NH}_{4}\right) 6 \mathrm{Mo}_{7} \mathrm{O}_{24} .4 \mathrm{H}_{2} \mathrm{O}\right)\right]$. The absorbance was measured using a UV-Vis spectrophotometer at $\lambda 485 \mathrm{~nm}$.

\section{RESULT}

This research is an experimental study with a Pre and Posttest Randomized Control Group Design. The research was done from February 2020 to July 2020. The research was done at the Pharmacology Laboratory College of Pharmacy foundation Semarang. This research had received an ethical approval number 094/CN/SW/KEPK-STIFAR/EC/I/2020 


\section{STRADA Jurnal Ilmiah Kesehatan}

DOI: $10.30994 /$ sjik.v9i2.510

ISSN: 2252-3847 (print); 2614-350X (online)

Vol.9 No.2 November 2020 Page. 1595-1604

Table 1. Phytochemical Screening and TLC result

\begin{tabular}{ccc}
\hline Compound & \multicolumn{2}{c}{ Result } \\
\cline { 2 - 3 } & Fresh Juice & TLC \\
\hline Flavonoid & + & Rf $1: 0,76$ \\
& & Rf $2: 0,59$ \\
\hline Alkaloid & + & Rf : 0,73 \\
\hline Tannin & + & Rf : 0,39 \\
\hline Saponin & + & Rf : 0.48 \\
\hline Steroid/ & - & Rf : - \\
Triterpenoid & & \\
\hline
\end{tabular}

The result of measuring the levels of urea, creatinine, and catalase enzyme activity can be seen in table 2,3, and 4 .

Table 2. Mean \pm SD of Decrease Measurement Test and the Decrease Percentage of Ureum Levels

\begin{tabular}{|c|c|c|c|c|}
\hline \multirow{2}{*}{ Group } & \multicolumn{3}{|c|}{ Mean \pm SD $(\mathrm{mg} / \mathrm{dL})$} & \multirow{2}{*}{$\begin{array}{c}\text { Decrease } \\
\text { Percentage } \\
(\%)\end{array}$} \\
\hline & $1^{\text {st }}$ Day & $15^{\text {th }}$ Day & 29th Day & \\
\hline Normal control & $\begin{array}{c}30,06 \pm \\
8,44\end{array}$ & $\begin{array}{c}28,46 \pm \\
2,33\end{array}$ & $\begin{array}{l}33,92 \pm \\
7,29\end{array}$ & $\begin{array}{c}-19,60 \pm \\
24,58\end{array}$ \\
\hline $\begin{array}{c}\text { Negative control (CMC Na } \\
0.5 \%)\end{array}$ & $\begin{array}{c}28,08 \pm \\
4,75\end{array}$ & $\begin{array}{l}45,74 \pm \\
8,48\end{array}$ & $\begin{array}{l}49,80 \pm \\
10,13\end{array}$ & $-8,71 \pm 6,80$ \\
\hline $\begin{array}{l}\text { Positive control(Curcumin } \\
50 \mathrm{mg} / \mathrm{KgBW})\end{array}$ & $\begin{array}{c}36,38 \pm \\
4,00\end{array}$ & $\begin{array}{c}35,28 \pm \\
6,96\end{array}$ & $\begin{array}{c}28,52 \pm \\
8,54\end{array}$ & $18,10 \pm 23,00$ \\
\hline Strawberry Juice $3 \mathrm{~g} / \mathrm{KgBW}$ & $\begin{array}{c}33,56 \pm \\
3,51\end{array}$ & $\begin{array}{c}42,58 \pm \\
6,20\end{array}$ & $\begin{array}{l}17,12 \pm \\
7,35\end{array}$ & $59,10 \pm 16,64$ \\
\hline Strawberry Juice $6 \mathrm{~g} / \mathrm{KgBW}$ & $\begin{array}{c}31,92 \pm \\
4,34\end{array}$ & $\begin{array}{l}48,40 \pm \\
7,03\end{array}$ & $\begin{array}{c}21,68 \pm \\
9,51\end{array}$ & $54,64 \pm 20,98$ \\
\hline Strawberry Juice $9 \mathrm{~g} / \mathrm{KgBW}$ & $\begin{array}{l}30,16 \pm \\
7,06\end{array}$ & $\begin{array}{c}38,62 \pm \\
8,66\end{array}$ & $\begin{array}{c}19,58 \pm \\
14,47\end{array}$ & $48,94 \pm 34,72$ \\
\hline
\end{tabular}

Table 3. Mean \pm SD of Decrease Measurement Test and Decrease Percentage of Creatinine Levels

\begin{tabular}{|c|c|c|c|c|c|}
\hline \multirow{2}{*}{ Group } & \multicolumn{4}{|c|}{ Mean \pm SD $(\mathrm{mg} / \mathrm{dL})$} & \multirow{2}{*}{$\begin{array}{c}\text { Decrease } \\
\text { Percentage } \\
(\%)\end{array}$} \\
\hline & $1^{\text {st }}$ Day & $15^{\text {th }}$ Day & & $2^{\text {th }}$ Day & \\
\hline Normal control & $0,67 \pm 0,22$ & $\begin{array}{l}0,52 \\
0,27\end{array}$ & \pm & $0,51 \pm 0,18$ & $-3,75 \pm 18,95$ \\
\hline $\begin{array}{l}\text { Negative control } \\
\text { (CMC Na } 0.5 \%)\end{array}$ & $0,51 \pm 0,17$ & $\begin{array}{l}0,53 \\
0,08\end{array}$ & \pm & $0,50 \pm 0,07$ & $1,97 \pm 25,17$ \\
\hline $\begin{array}{l}\text { Positive control } \\
\text { (Curcumin } 50 \\
\text { mg/KgBW) }\end{array}$ & $0,56 \pm 0,24$ & $\begin{array}{l}0,45 \\
0,06\end{array}$ & \pm & $0,41 \pm 0,03$ & $7,17 \pm 17,95$ \\
\hline $\begin{array}{c}\text { Strawberry Juice } \\
\text { 3g/KgBW }\end{array}$ & $0,72 \pm 0,19$ & $\begin{array}{l}0,52 \\
0,15\end{array}$ & \pm & $0,51 \pm 0,12$ & $-1,65 \pm 21,83$ \\
\hline
\end{tabular}




\section{STRADA Jurnal Ilmiah Kesehatan}

DOI: $10.30994 /$ sjik.v9i2.510

ISSN: 2252-3847 (print); 2614-350X (online)

Vol.9 No.2 November 2020 Page. 1595-1604

Strawberry Juice $6 \mathrm{~g} / \mathrm{KgBW}$

$\begin{array}{cc} & 0,53 \\ 0,59 \pm 0,19 & 0,18 \\ & 0,58 \\ 0,43 \pm 0,09 & 0,17\end{array}$

$\pm$

$0,33 \pm 0,12 \quad 36,42 \pm 20,73$

Strawberry Juice $9 \mathrm{~g} / \mathrm{KgBW}$

0,17

$\pm$

$0,44 \pm 0,09 \quad 20,22 \pm 24,74$

Table 4. Mean \pm SD of Increase Measurement and Increase Precentage of Catalase Enzyme Activity

\begin{tabular}{|c|c|c|c|c|}
\hline \multirow{2}{*}{ Group } & \multicolumn{3}{|c|}{$\operatorname{Mean} \pm \operatorname{SD}(\mathrm{U} / \mathrm{ml})$} & \multirow{2}{*}{$\begin{array}{c}\text { Increase } \\
\text { Percentage } \\
(\%)\end{array}$} \\
\hline & $1^{\text {st }}$ Day & $15^{\text {th }}$ Day & $2^{\text {th }}$ Day & \\
\hline Normal control & $\begin{array}{c}48,31 \pm \\
5,62\end{array}$ & $\begin{array}{c}47,82 \pm \\
5,24\end{array}$ & $\begin{array}{l}50,22 \pm \\
5,27\end{array}$ & $5,14 \pm 4,80$ \\
\hline $\begin{array}{c}\text { Kontrol Negatif (CMC Na } \\
0.5 \%)\end{array}$ & $\begin{array}{c}44,28 \pm \\
7,12\end{array}$ & $\begin{array}{c}30,49 \pm \\
2,22\end{array}$ & $\begin{array}{c}32,58 \pm \\
2,16\end{array}$ & $6,91 \pm 1,58$ \\
\hline $\begin{array}{c}\text { Positive control (Curcumin } \\
50 \mathrm{mg} / \mathrm{KgBW})\end{array}$ & $\begin{array}{c}44,65 \pm \\
5,07\end{array}$ & $\begin{array}{l}32,71 \pm \\
3,65\end{array}$ & $\begin{array}{c}45,41 \pm \\
3,96\end{array}$ & $\begin{array}{c}39,20 \pm \\
4,84\end{array}$ \\
\hline $\begin{array}{l}\text { Strawberry Juice } \\
\text { 3g/KgBW }\end{array}$ & $\begin{array}{c}41,23 \pm \\
5,26\end{array}$ & $\begin{array}{c}30,46 \pm \\
6,58\end{array}$ & $\begin{array}{c}39,45 \pm \\
6,80\end{array}$ & $\begin{array}{c}30,42 \pm \\
6,78\end{array}$ \\
\hline $\begin{array}{l}\text { Strawberry Juice } \\
6 \mathrm{~g} / \mathrm{KgBW}\end{array}$ & $\begin{array}{c}45,97 \pm \\
2,50\end{array}$ & $\begin{array}{c}33,66 \pm \\
3,28\end{array}$ & $\begin{array}{c}46,18 \pm \\
4,20\end{array}$ & $\begin{array}{c}37,29 \pm \\
2,42\end{array}$ \\
\hline $\begin{array}{c}\text { Strawberry Juice } \\
\text { 9g/KgBW }\end{array}$ & $\begin{array}{c}42,40 \pm \\
7,31\end{array}$ & $\begin{array}{c}32,18 \pm \\
6,78\end{array}$ & $\begin{array}{c}49,35 \pm \\
6,66\end{array}$ & $\begin{array}{c}55,54 \pm \\
13,92 \\
\end{array}$ \\
\hline
\end{tabular}

\section{DISCUSSION}

This study aim to determine the effect of giving and effective dose of strawberry juice (Fragaria ananassa Duchessne) on urea and creatinine levels in Isoniazis-induced male Wistar rats. Sample used were strawberry (Fragaria ananassa Duchessne).

The orientation of strawberry juice was done and result volume of juice was $20.38 \mathrm{ml}$ for $30 \mathrm{~g}$ of strawberries. Preliminary test (phytochemical screening) and affirmation test (Thin Layer Chromatography) of strawberry juice was done. The purpose of the phytochemical screening test was to determined the secondary metabolite compounds contained in strawberry juice. From the test results, it is known that strawberry juice contains flavonoid, alkaloid, tannin and saponin. The most common compounds in strawberry are ellagitannin, anthocyanin and flavonol. Flavonol that identified in strawberry are derivative of quercetin and kaempferol (Aaby et al., 2007).

Pharmacological activity tests was done on testing animal to determine the pharmacological activity of strawberry juice in reducing urea and creatinine levels and increasing the activity of the enzyme catalase. Normal urea levels are 12.3-24.6 mg / dL (Mary and Charles, 2008). Normal creatinine levels are 0.2-0.5 mg / dL (Mary and Charles, 2008).

To determine the antioxidant activity of strawberry (Fragaria ananassa Duchessne) juice on decreasing levels of urea and creatinine, and increasing activity of the enzyme catalase seen from the percent decrease in levels of urea, creatinine, and percent increase in catalase enzyme activity. The decrease percentage of urea, creatinine, and increase percentage in catalase activity that obtained were tested for normality and homogenity test. The normality test shows that the data is normally distributed ( $>>0.05)$ and the homogenity test shows that the data is homogeneously distributed ( $p>0.05)$. 


\section{STRADA Jurnal Ilmiah Kesehatan}

DOI: $10.30994 /$ sjik.v9i2.510

ISSN: 2252-3847 (print); 2614-350X (online)

Vol.9 No.2 November 2020 Page. 1595-1604

A parametric test for the percent reduction in urea, creatinine, and increase of catalase activity was performed using the One-Way Anova test with confidence level of 95\%. The results of the One-Way Anova test for the percentage of reduction in urea and creatinine levels showed a difference in urea levels between groups with a value of $p=0.000$ and a decrease in creatinine levels with a value of $p=0.007$. The increase activity of catalase enzyme showed difference in urea levels between groups with a value of $p=0.000$. A Post Anova test was performed, called Post-hoc LSD test to see the significance value between groups.

Post-hoc LSD test results In the positive control group compared with the strawberry juice group (Fragaria ananassa Duchessne) at doses of $3 \mathrm{~g} / \mathrm{kgBW}, 6 \mathrm{~g} / \mathrm{kgBW}$, and $9 \mathrm{~g} /$ $\mathrm{kgBW}$, the result were not significant. This explains that strawberry juice (Fragaria ananassa Duchessne) doses of $3 \mathrm{~g} / \mathrm{kgBW}, 6 \mathrm{~g} / \mathrm{kgBW}$, and $9 \mathrm{~g} / \mathrm{kgBW}$ were able to reduce levels of urea and creatinine in Isoniazid-induced rats by comparable to the positive control (Curcumin) at a dose of $50 \mathrm{mg} / \mathrm{kg}$ in rats. This is the base for selecting an effective dose of strawberry juice (Fragaria ananassa Duchessne) that the dose of $3 \mathrm{~g} / \mathrm{kgBB}$ is an effective dose to reduce urea and creatinine levels in rats.

Isoniazid used as an inducer can damage the kidney. The mechanism of isoniazid in damaging the kidney begin with the change of isoniazid by N-acetyltransferase2 (NAT-2) to acetyl isoniazid, which will then be hydrolyzed to acetylhydrazine. Acetylhydrazine with the help of cytochrome P4502E1 enzyme converted to N-hydroxyacetyl hydrazine, which will further be converted into acetyldiazine. Acetyldiazine which is an intermediate product will be change into free radical (Tostmann et al., 2008).

One of the cause of increased levels of urea and creatinine is free radical. Free radicals are a nephrotoxic mechanism of isoniazid, and antioxidants can be protecting against free radical cause nephrotoxic and ROS (reactive oxygen species) induce in the kidney. The increase in free radical and ROS will cause cell death where the content of the cell that come out will bind to the fibronectin protein in the tubular lumen. This will cause a blockage in the form of a cylinder so that urea and creatinine cannot be excreted properly (Michael, 2013). In the research of Muhyi et al., (2014) it was proven that the use of isoniazid can cause an increase in creatinine and urea levels.

In addition, oxidative stress due to increased free radical production causes a decrease in endogenous antioxidants in the liver such as catalase, superoxide dismutase, and glutathione peroxidase (Zalukhu et al., 2016). Free radicals that formed by oxygen molecule called Reactive Oxygen Species (ROS). ROS will be converted by the enzymatic antioxidant SOD to $\mathrm{H}_{2} \mathrm{O}_{2}$ and then the catalase enzyme will convert $\mathrm{H}_{2} \mathrm{O}_{2}$ to $\mathrm{H}_{2} \mathrm{O}$ and $\mathrm{O}_{2}$. Continuously exposure of free radicals will cause enzyme activity decrease, so that $\mathrm{H}_{2} \mathrm{O}_{2}$ becomes toxic hydroxyl radicals. So that exogenous antioxidants are needed to neutralize free radical (Sy et al., 2015). Antioxidant can stop the production of Reactive Oxygen Species (ROS) which will cause cell damage such as obstruction in the urinary tract (Shah, 2014).

In this study, it was shown that strawberry juice (Fragaria ananassa Duchessne) was able to reduce levels of urea and creatinine and increase the activity of the enzyme catalase. This can occur because strawberry juice (Fragaria ananassa Duchessne) contains flavonoid, alkaloid, tannin, saponin, and vitamin C compound. In addition, strawberry (Fragaria ananassa Duchessne) were assumed to contain marker quercetin compounds (Aaby et al., 2007). These compounds have a role as antioxidants.

Flavonoids have antioxidant activity that can inhibit lipid peroxidation by reducing free radicals and increasing intracellular concentrations of glutathione (Karimi et al., 2009). 


\section{STRADA Jurnal Ilmiah Kesehatan}

DOI: $10.30994 /$ sjik.v9i2.510

ISSN: 2252-3847 (print); 2614-350X (online)

Vol.9 No.2 November 2020 Page. 1595-1604

The mechanism of flavonoids as a breakdown of calcium oxalate crystals, namely flavonoids will bind with calcium to form complex compounds into Ca-flavonoids (Susilo, et al. 2018)

Alkaloid class compounds can be potent as antioxidants. Alkaloid compounds have the ability to stop free radical chain reactions, alkaloids also play an important role in protecting cells from the effects of radiation and drug toxicity (Yuhermita and Juniarti, 2011). In addition, alkaloid also have been shown to have a strong inhibitory effect on lipid peroxidation in tissue isolation by increasing the enzyme superoxide dismutase (SOD). This inhibition will be able to cause the return of $\mathrm{Na}+$ and $\mathrm{H}_{2} \mathrm{O}$ function to the cells so that kidney function return to normal (Shelkea et al., 2011).

Tannins have the ability to bind free radicals, tannins are very effective as electron donors or hydrogen atoms, this happens because tannins have hydroxyl groups and conjugated double bonds that allow electron delocalization (Hagerman, 1998). Vitamin C and tannin act as free radical scavengers that bind directly to free radicals or toxic drug metabolites (Hassanin et al., 2013) (Gulcin et al., 2010).

Saponins have anti-oxidative and radical-binding properties by forming hydroperoxides as intermediates and can contribute hydrogen to radical compounds thus ending the radical chain reaction (Xiong et al., 2012).

Quercetin is able to improve the redox state of cells and increase the expression of cglutamethylsin synthesis, which is a rate-limiting step in the synthesis of antioxidant glutathione peroxidase (GSH-Px). Increased activity of T-SOD, GSH-Px will have a protective effect on the glomerulus and proximal tubule which causes a decrease in tissue damage mediated by free radical reactions (Myhrstad et al, 2002).

\section{CONCLUSSION}

Strawberry juice (Fragaria ananassa Duchessne) has antioxidant activity which act as a nephroprotector. The treatment of strawberry juice (Fragaria ananassa Duchessne) can reduce levels of urea and creatinine and increase the activity of catalase enzyme in Isoniazidinduced rats. The effective dose of strawberry juice (Fragaria ananassa Duchessne) which can reduce urea and creatinine levels and increase catalase enzym activity in Isoniazidinduced rats is $3 \mathrm{~g} / \mathrm{kgBW}$.

\section{REFERENCES}

Aaby, K., Skrede, G., and Wrolstad, R. E. 2005. Phenolic composition and antioxidant activities in flesh and achenes of strawberries (Fragaria ananassa). Journal of Agricultural and Food Chemistry. 53:4032-4040.

Aaby, K., Dag Ekeberg, and Greete Skrede. 2007. Characterization of Phenolic Compounds in Strawberry (Fragaria $\times$ ananassa) Fruits by Different HPLC Detectors and Contribution of Individual Compounds to Total Antioxidant Capacity. Journal of Agricultural and Food Chemistry. 55:4395-4406.

Appel GB, Bhat P. 2006. Nephrology VIII. Tubulointerstitial diseases. In. ACP Medicine. Apriana, R., Supriyatin., Rahayu, S. 2016. Pengaruh Aktivitas Fisik Maksimal Dan Ekstrak Daun Bambu Manggong (Gigantochloa manggong) Terhadap Aktivitas Katalase Pada Hati Tikus Putih (Rattus norvegicus). BIOMA Biologi UNJ Press. 12(1): 34-41.

Arifin, H., Anggraini, N., Handayani, D., dan Rasyid, R. 2006 . Standarisasi Ekstrak Etanol Daun Eugenia cumini Merr. Journal Sains Teknologi Farmasi. 11(2): 88-93

Baker RJ, Pusey CD. 2004. The changing profi le of acute tubulointerstitial nephritis. Nephrol Dial Transplant. 19: 8-11 


\section{STRADA Jurnal Ilmiah Kesehatan}

DOI: $10.30994 /$ sjik.v9i2.510

ISSN: 2252-3847 (print); 2614-350X (online)

Vol.9 No.2 November 2020 Page. 1595-1604

Brunner \& Suddarth. 2001. Buku Ajar Keperawatan Medikal Bedah. Volume II. Edisi 8. Jakarta: EGC.

Endarini, Lully H. 2016. Farmakognosi dan Fitokimia. Cetakan 1. Jakarta: Pusdik SDM Kesehatan

Departemen Kesehatan RI. 1979. Farmakope Indonesia Edisi III. Jakarta: Departemen Kesehatan Republik Indonesia.

D G A Suryawan, dkk.,2016, Gambaran Kadar Ureum dan dan kreatinin serum pada pasien gagal ginjal kronis yang menjalani terapi hemodialysis di RsUD Sanjiwani Gianyar, Meditory, Vol. 4, No.2.Desember, 146-153.

Gulcin I, Huyut Z, Elmastas M, Hassan Y., Aboul-Enin. 2010. Radical Scavenging adn Antioxidant Activity of Tannic Acid. Arabian Journal of Chemistry. 3:43-53.

Guyton, A.C., and Hall, J.E. 2008. Buku Ajar Fisiologi Kedokteran Edisi ke-11. Jakarta: EGC.

Hagerman, A. E., Rice M. E., and Richard N. T. 1998. Mechanisms of Protein Precipitation For Two Tannins, Pentagalloyl Glucose And Epicatechin 16 (4-8) Catechin (Procyanidin). JAFC. 46. (7): 2550-2595.

Hassanin KMA, Hashem KS, Abdel-Kawl SH. 2013. Hepatoprotective effects of Vitamin $\mathrm{C}$ and Micronized Vitamin C Against Paracetamol Induced Hepatotoxicity in Rats: A Comparative Study. International Journal of Biochemistry and Biotechnology. 2(7):474-483.

Hayati, E.K., Jannah, A., dan Ningsih, R. 2012. Identifikasi Seyawa Dan Aktivitas Antimalaria In Vivo Ekstrak Etil Asetat Tanaman Anting-Anting (Acalypha indica L.). Molekul. 7(1): 20-32.

Iwai, Kunihisa, Natsuko Nakaya, Yoshihiro Kawasaki, and Hajime Matsue. 2002. Antioxidative Functions of Natto, A Kind of Fermented Soybeans: Effect on LDL Oxidation and Lipid Metabolism in Cholesterol-Fed Rats. Journal of Agricultural and Food Chemistry. 50:3597-3601.

Kahkonen, M. P., Hopia, A. I., and Heinonen, M. (2001). Berry phenolics and their antioxidant activity. J. Agric. Food Chem. 49:4076-4082.

Karimi G, Khoei A, Omidi A, Kalantari M, Bababei J, Elahe T, Razavi BM. 2010. Protective effect of aqueous and ethanolic extracts of Portulaca oleracea againts cisplatin induced nephrotoxicity. Iran. J. Basic Medical Sciences. 13: 31-5

Katzung. 2008. Basic Clinical Pharmacology. Edisi 9. Mc. Garw Hill. 369

Kumalaningsih. 2007. Antioksidan Alami Penangkal Radikal Bebas. Surabaya:Trubus Agrisarana. Hal 65.

Linn. in Urolithiasis Induced by Ethylene Glycol Model. Iranian Journal of Pharmacology \& Therapeutics, 13:35-39

Mary, L.A., Giknis, and Charles, B.C.D.V.M. 2008. Clinical Labolatory Parameters. USA: Charles River.

Michael. 2013. Pengaruh ekstrak metanol daun kesum (Polygonum minus Huds.) terhadap peningkatan kadar kreatiin dan ureum serum tikus putih galur wistar terinduksi sisplastin. Pontianak. Fakultas Kedokteran Universitas Tanjungpura

Muhyi, Y.D., Zulfia, Carolia, N,., Tjiptaningrum, A. 2014. Pengaruh Pemberian Ekstrak Kulit Manggis (Garcinia mangostana L.) Terhadap Kadar Ureum Dan Kreatinin Tikus Putih (Rattus norvegicus) Jantan Galur Sprague dawley Yang Diinduksi Isonazid. Jurnal. 23. (37): 158-167.

Myhrstad, M.C., Carlsen, H., Nordstrom, O., Blomhoff, R., dan Moskau, J.J. 2002. Flavonoids Increase the Intracellular Glutathione Level by Transactivation of the 


\section{STRADA Jurnal Ilmiah Kesehatan}

DOI: $10.30994 /$ sjik.v9i2.510

ISSN: 2252-3847 (print); 2614-350X (online)

Vol.9 No.2 November 2020 Page. 1595-1604

Gamma-glutamylcysteine Synthetase Catalytical Subunit Promoter. Free Radical Biology and Medicine. (32): 386-393.

Nuria, M.C., Faizatun, A., Sumantri. 2009. Uji Aktivitas Antibakteri Ekstrak Etanol Daun Jarak (Jatropha curcas L) Terhadap Bakteri Staphylococcus aureus ATCC 25923, Escherichia coli ATCC 25922, dan Salmonella typhi ATCC 1408. Mediagro. 5(2): 26-37.

Oszmianski, J., Aneta Wojdyto. 2009. Comparative study of phenolic content and antioxidant activity of strawberry puree, clear, and cloudy juices. Eur Food Res Technol. 228:623-631.

Robinson, T. 1995. Kandungan Organik Tumbuhan Tinggi. Bandung : ITB Press.

Sharma, V., dan Paliwal, R. 2012. Chemo Protective Role of Moringa oleifera and its Isolated saponin againts DMBA induced tissue damage in male mice. Int J Drug Dev \& Res. 4. (4): 215-228.

Shah, A.P., Shenal B. Patel, Kirti V. Patel, Tejal R. Gandhi. 2014. Effect of Citrus Medica

Shelkea, T.T, Bhaskarb, V.H., Adkara, P.P, Jhaa, U., Oswala, R.J. 2011. Nephroprotective Activity of Ethanolic Extract of Stem Barks of Crataeva nurvala Buch Hum. Int J Phar Sci \& Res. 2. (10): 2712-2717.

Susilo Joko, Ulya H , Furdiyanti NH, 2018, Pengaruh Pemberian Ekstrak Daun Apium Graveolens L. Terhadap Penurunan Kadar Kreatinin Dan Ureum Serum Tikus Yang Diinduksi Etilen Glikol, Prosiding Seminar Nasional Unimus, Volume 1, ISSN: 26543257, Halaman 104-113

Sy, E., Kadri, H., Yerizel, E. 2015. Efek Pemberian Vitamin C Terhadap Aktifitas Katalase Hati Tikus Galur Wistar yang Terpapar Ion Pb. Jurnal Kesehatan Andalas. 4(1):279285.

Tostmann, A., M. J. Boeree, R. E. Aamoutse, W. C. M. D. Lange, A. J. A. M. V. Ven, dan R. Dekhuijzen. 2008. Antituberculosis drug-induced hepatoxicity: concise up-to-date review. J Gastroenterol Hepatol. 23. (2): 192-202.

Untari, E. K., Sri W., dan Agustia Damayanti. 2014. Efek Fraksi n-heksana Kulit Hylocereus polyrhizus Terhadap Aktivitas Katalase Tikus Stres Oksidatif. Pharm Sci Res. 1(3): 141-153.

Verdiansah. 2016. Pemeriksaan Fungsi Ginjal. CDK. 43(2):148-154.

Xiong, Shuang-Li, Da-Bin Hou, Ni Huang and Anlin Li. 2012. Preparation and biological activity of saponin ophiopogon japonicus. AJPP. 6. (26): 1964-1970.

Yuhernita; dan Juniarti.2011. Analisis Senyawa Metabolit Sekunder Dari Ekstrak Metanol Daun durian Yang Berpotensi Sebagai Antioksidan. Makara, Sains. 15. (1): 48-52.

Zalukhu, M.L., Phyma, A.R., Pinzon, R.T. 2016. Proses Menua, Stres Oksidatif, dan Peran Antioksidan. CDK. 43(10): 733-736. 